Dr:

FFA 05 得3

OSTI

\title{
Effect of Boron on Post Irradiation Tensile Properties of Reduced Activation Ferritic Steel (F-82H) Irradiated in HFIR
}

\author{
K. Shiba, M. Suzuki, A. Hishinuma, and \\ J. E. Pawel
}

\section{DISCLAIMER}

This report was prepared as an account of work sponsored by an agency of the United States Government Neither the United States Government nor any agency thereof, nor any of their employees, makes any warranty, express or implied, or assumes any legal liability or responsibility for the accuracy, completeness, or usefulness of any information, apparatus, product, or brocess disclosed, or represents that its use would not infringe privately owned rights. Referprocess disclosed, or represents that its use woul, process, or service by trade name, trademark, ence herein to any specific cons not necessarily constitute or imply its endorsement, recommanufacturer, or otherwise does not necessariles Government or any agency thereof. The views mendation, or favoring by the United herein do not necessarily state or reflect those of the and opinions of authors expressed herein do noted

*Research sponsored by the Office of Fusion Energy, U.S. Department of Energy, under contract DE-AC05-84OR21400 with Lockheed Martin Energy Systems.

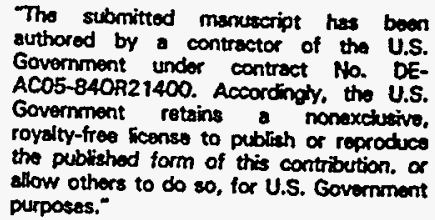

purposes." 
Kiyoyuki Shiba ${ }^{1}$, Masahide Suzuki ${ }^{1}$, Akimichi Hishinuma ${ }^{1}$ and Janet E. Pawel ${ }^{2}$

\title{
EFFECT OF BORON ON POST IRRADIATION TENSILE PROPERTIES OF REDUCED ACTIVATION FERRITIC STEEL (F-82H) IRRADIATED IN HFIR
}

REFERENCE: Shiba, K., Suzuki, M., Hishinuma, A., and Pawel, J. E., " Effect of Boron on Post Irradiation Tensile Properties of Reduced Activation Ferritic Steel (F-82H) Irradiated in HFIR," Effects of Radiation on Materials: 17th Volume, ASTM STP 1270, David S. Gelles, Randy K. Nanstad, Arvind S. Kumar and Edward A. Little, Editors, American Society For Testing and Materials, Philadelphia, 1995.

\begin{abstract}
Reduced activation ferritic / martensitic steel, F-82H (Fe-8Cr-2W$\mathrm{V}-\mathrm{Ta}$ ), was irradiated in the High Flux Isotope Reactor (HFIR) to doses between 11 and $34 \mathrm{dpa}$ at 400 and $500^{\circ} \mathrm{C}$. Post irradiation tensile tests were performed at the nominal irradiation temperature in vacuum. Some specimens included ${ }^{10} \mathrm{~B}$ or natural boron (nB) to estimate the helium effect on tensile properties.

Tensile properties including the $0.2 \%$ offset yield stress, the ultimate tensile strength, the uniform elongation and the total elongation were measured. The tensile properties were not dependent on helium content in specimens irradiated to $34 \mathrm{dpa}$, however ${ }^{10} \mathrm{~B}$-doped specimens with the highest levels of helium showed slightly higher yield strength and less ductility than boron-free specimens. Strength appears to go through a peak, and ductility through a trough at about $11 \mathrm{dpa}$. The irradiation to more than $21 \mathrm{dpa}$ reduced the strength and increased the elongation to the unirradiated levels.
\end{abstract}

KEYWORDS: Reduced Activation, Ferritic / martensitic steel, HFIR irradiation, Tensile properties, Boron-10 dope, helium effect

1 Engineer, principal research engineer and group leader, respectively, Department of Materials Science and Engineering, Japan Atomic Energy Research Institute, Tokai-mura Ibaraki-ken 319-11.

2 Research staff member, Metals and Ceramics Division, Oak Ridge National Laboratory, P.O. Box 2008, Oak Ridge, TN 37831-6376, USA. 


\section{INTRODUCTION}

Ferritic steels are one of the candidate alloys for nuclear fusion reactors because of their good thermophysical properties, their superior swelling resistance, and the low corrosion rate in contact with potential breeder and coolant materials. Another attraction of ferritic steels is the possibility of low activation. Several kinds of ferritic steels are now under investigation. The typical alloy compositions of ferritic / martensitic steels are 2.25 $\mathrm{Cr}, 7-9 \mathrm{Cr}$ and $12 \mathrm{Cr}$.

Alloy F-82H was developed as a reduced activation ferritic steel by Japan Atomic Energy Research Institute (JAERI) and Nippon Kokan KK (NKK) [1]. Some characteristics have been researched in the unirradiated conditions [2-4]; however the study of the behavior under irradiation has just started [ $[5]$. The effect of helium on mechanical properties of irradiated ferritic steels has been reported [6,7]. Several techniques can be applied to generate helium during irradiation in fission reactor. The addition of ${ }^{10} \mathrm{~B}$ to steel can generate helium according to the ${ }^{10} \mathrm{~B}(\mathrm{n}, \alpha){ }^{7} \mathrm{Li}$ reaction [8]. This technique was used in this investigation to study the effect of helium on tensile properties.

\section{EXPERIMENTAL PROCEDURE}

The alloy investigated was an 8Cr-1W-V-Ta ferritic / martensitic steel (F-82H). The same composition with boron additions was also prepared for this experiment to investigate the helium effect on tensile properties. The three alloys are standard $\mathrm{F}-82 \mathrm{H}$, ${ }^{10} \mathrm{~B}$-doped F-82H and natural-boron doped F-82H; hereafter they are called as STD F$82 \mathrm{H},{ }^{10} \mathrm{~B}$ F- $82 \mathrm{H}$ and $\mathrm{nB}$ F-82H, respectively. The ${ }^{10} \mathrm{~B}$ was added for the production of helium during irradiation, and $\mathrm{nB} F-82 \mathrm{H}$ specimens were prepared in order to study the effect of boron itself. The chemical compositions of these alloys are given in TABLE 1 . The amounts of ${ }^{10} \mathrm{~B}$ or $\mathrm{nB}$ were both about 300 appm. Pure ${ }^{10} \mathrm{~B}$ was used for ${ }^{10} \mathrm{~B} F-82 \mathrm{H}$, while natural boron includes about $20 \%$ of ${ }^{10} \mathrm{~B}$. All three alloys were cast into $25 \mathrm{~kg}$ ingots individually, then hot rolled to $10 \mathrm{~mm}$ plates at $1200^{\circ} \mathrm{C}$. The normalizing treatment for these alloys was $0.5 \mathrm{~h}$ at $1040^{\circ} \mathrm{C}$, and then they were tempered for $1.5 \mathrm{~h}$ at $720^{\circ} \mathrm{C}$. The structure after tempering was a tempered lath martensitic structure for all steels.

The steels were fabricated into SS-3 type sheet tensile specimens which are 25.4 $\mathrm{mm}$ in length, $4.95 \mathrm{~mm}$ in width and $0.76 \mathrm{~mm}$ in thickness. The gage section of this specimen was $7.62 \mathrm{~mm}$ in length and $1.52 \mathrm{~mm}$ in width. 
These tensile specimens were irradiated in the High Flux Isotope Reactor (HFIR) target position capsules HFIR-MFE-JP-13, -16 and -14 . The details of irradiation are given elsewhere [9]. The peak fluence of fast neutrons $\left(E>1 \mathrm{MeV}\right.$ ) was about $2.0 \times 10^{26}$ neutrons $/ \mathrm{m}^{2}$ for JP-13 and -16 , and about $3.8 \times 10^{26}$ neutrons $/ \mathrm{m}^{2}$ for JP-14. These fluences correspond to 18 and $34 \mathrm{dpa}$ in atom displacement damage. The neutron flux varies in the axial direction of the capsule, so that the displacement damage of each specimen varied, depending on its position. The analyses of the flux monitors are not completed yet, therefore the irradiation information used in this paper is approximate. The high cross section of ${ }^{10} \mathrm{~B}(\mathrm{n}, \alpha){ }^{7} \mathrm{Li}$ (4000 barns) and the low thermal flux cause complete burn up of ${ }^{10} \mathrm{~B}$ in the early stages of irradiation [8]. Damage by the recoiled alphas is negligible compared to the neutron damage level investigated in this experiment. About $20 \%$ of ${ }^{10} \mathrm{~B}$ is included in natural $\mathrm{B}$ and pure ${ }^{10} \mathrm{~B}$ is used for the ${ }^{10} \mathrm{~B} F-82 \mathrm{H}$. Therefore, the amount of helium in ${ }^{10} \mathrm{~B} F-82 \mathrm{H}$ is about 300 appm and that in natural B F-82H is about 60 appm after irradiation.

An Instron universal testing machine was used for tensile testing. Tensile testing was carried out at the nominal irradiation temperature in vacuum for each specimen. The strain rate was $1 \times 10^{-3} / \mathrm{s}$. The $0.2 \%$ proof stress (YS), ultimate tensile stress (UTS), uniform elongation $(\mathrm{Eu})$ and total elongation (Et) were calculated from the loaddisplacement chart.

TABLE 1--Chemical composition of alloys (wt\%)

\begin{tabular}{lccccccc}
\hline & $\mathrm{Fe}$ & $\mathrm{Cr}$ & $\mathrm{W}$ & $\mathrm{V}$ & $\mathrm{Ta}$ & Total B & $10 \mathrm{~B}$ \\
\hline $\mathrm{F} 82 \mathrm{H}$ & bal. & 7.44 & 2.0 & 0.20 & 0.04 & $\ldots$ & $\ldots$ \\
$\mathrm{F} 82 \mathrm{H}+\mathrm{nB}$ & bal. & 7.49 & 2.1 & 0.20 & 0.04 & 0.0060 & 0.0012 \\
$\mathrm{~F} 82 \mathrm{H}+{ }^{10} \mathrm{~B}$ & bal. & 7.23 & 2.1 & 0.22 & 0.04 & 0.0058 & 0.0058 \\
\hline & & & & & & & \\
\hline & $\mathrm{C}$ & $\mathrm{Si}$ & $\mathrm{Mn}$ & $\mathrm{P}$ & $\mathrm{S}$ & $\mathrm{Al}$ & $\mathrm{N}$ \\
\hline $\mathrm{F} 82 \mathrm{H}$ & 0.100 & 0.14 & 0.49 & 0.001 & 0.001 & 0.019 & 0.002 \\
$\mathrm{~F} 82 \mathrm{H}+\mathrm{nB}$ & 0.099 & 0.15 & 0.50 & 0.001 & 0.001 & 0.021 & 0.001 \\
$\mathrm{~F} 82 \mathrm{H}+{ }^{10} \mathrm{~B}$ & 0.098 & 0.17 & 0.50 & 0.001 & 0.001 & 0.021 & 0.002 \\
\hline
\end{tabular}




\section{RESULTS AND DISCUSSIONS}

Dose dependence

The tensile results before and after irradiation are listed in TABLE 2. FIG. 1 shows the yield stress and total elongation of STD F-82H irradiated at 400 and $500{ }^{\circ} \mathrm{C}$ as a function of neutron damage.

As shown in FIG. 1, all three types of alloys had some irradiation hardening after irradiation to the dose of $34 \mathrm{dpa}$ at $400^{\circ} \mathrm{C}$. Only ${ }^{10} \mathrm{~B} \mathrm{~F}-82 \mathrm{H}$ had the data at the dose of 11 dpa at this temperature and this was the maximum strength and minimum elongation in this experiment. The irradiation to $21 \mathrm{dpa}$ reduced the change in yield strength and recovered the elongation. There was no change in yield stress between $21 \mathrm{dpa}$ and $34 \mathrm{dpa}$, but there was a slight increase in elongation. STD F-82H showed the same dose dependence as ${ }^{10} \mathrm{~B}$ $\mathrm{F}-82 \mathrm{H}$ at more than $21 \mathrm{dpa}$. However, the reduction of yield stress of ${ }^{10} \mathrm{~B}$ from $11 \mathrm{dpa}$ to 21 dpa seems very large, compared to the other results $[6, \underline{10}-12]$. FIG. 2 illustrates the stress - strain diagrams of F-82H irradiated in several irradiation conditions from this experiment and others. The stress - strain curve of ${ }^{10} \mathrm{~B}$ F- $82 \mathrm{H}$ irradiated to $11 \mathrm{dpa}$ at 400 ${ }^{\circ} \mathrm{C}$ deformed in the same manner as the specimens irradiated at lower temperatures. These specimens ( 3 dpa and $11 \mathrm{dpa}$ ) exhibited necking just after yielding, so that they did not show any work hardening. These results demonstrate much irradiation hardening occurs at lower irradiation temperatures and it appears in the relatively early stages of irradiation at $250^{\circ} \mathrm{C}$. Since ${ }^{10} \mathrm{~B} \mathrm{~F}-82 \mathrm{H}$ irradiated to $11 \mathrm{dpa}$ at $400^{\circ} \mathrm{C}$ deformed similarly, this specimen might have been irradiated at a lower temperature than the nominal irradiation temperature.

Only results irradiated to more than $30 \mathrm{dpa}$ were obtained at $500^{\circ} \mathrm{C}$. Both of the boron doped specimens and STD F-82H showed the same strength and elongation as the unírradiated values at this temperature. The stress - strain curves of STD F-82H irradiated to $34 \mathrm{dpa}$ at 400 and $500^{\circ} \mathrm{C}$ shown in FIG. 2 demonstrate the specimens irradiated at 400 and $500^{\circ} \mathrm{C}$ deformed in the same manner and they are apparently different from the results at lower irradiation doses and temperature. The specimens irradiated to $34 \mathrm{dpa}$ at 400 and $500^{\circ} \mathrm{C}$ have some work hardening capacity. This means that recovery of the lath structure occurred at the higher irradiation temperatures, however some degradation of ductility occurred at $500^{\circ} \mathrm{C}$. One possible reason for this result is the coarsening of carbides or an aging effect, since helium production during irradiation in STD F-82H specimens is small. The irradiation time for both 21 and $34 \mathrm{dpa}$ specimens (which were irradiated in the same irradiation capsule) was about $45 \mathrm{Ms}$, while it was $25 \mathrm{Ms}$ for $11 \mathrm{dpa}$ specimens. This is sufficient to cause the coarsening of carbides even in the unirradiated condition [2]. 
Microstructural observation for the same F-82H irradiated in the Fast Flux Test Facility (FFTF) by Kohno et. al [5] showed partial recovery of lath martensite at both 400 and 500 ${ }^{\circ} \mathrm{C}$. This FFTF irradiation time was $29 \mathrm{Ms}$. It seems that the longer irradiation time generated much more recovery of the lath structure.

\section{The effect of boron addition}

Three types of steels were irradiated to investigate the helium effect on tensile properties. The differences between these three steels were small in all irradiation conditions in this experiment. FIG. 3 shows the yield strength and total elongation of boron-free and boron-doped F-82H irradiated to $34 \mathrm{dpa}$ at 400 and $500^{\circ} \mathrm{C}$ with changes of these properties. ${ }^{10} \mathrm{~B}$ F-82H had slightly higher strength than STD F-82H in all conditions, and the increase of yield strength due to irradiation was also larger. The strength of $\mathrm{nB} F-82 \mathrm{H}$ was lower than ${ }^{10} \mathrm{~B} F-82 \mathrm{H}$, but the differences between $\mathrm{nB}$ and STD were not consistent with helium content even though the $\mathrm{nB}$ specimens have more helium than STD F-82H at 34 dpa. The helium can affect the strength as small helium bubbles. Kimura et al. found tiny voids which caused higher swelling in boron-doped $9 \mathrm{Cr}$ ferritic steels irradiated in FFTF at $420^{\circ} \mathrm{C}$ [14]. Their boron-doped steels contained 30 wppm of natural boron. The slightly higher strength of ${ }^{10} \mathrm{~B}$ specimens might be caused by these helium cavities, but the helium produced from $\mathrm{nB}$ was not sufficient to make a difference in strength. Lithium is also produced with helium, according to the ${ }^{10} \mathrm{~B}(\mathrm{n}, \alpha){ }^{7} \mathrm{Li}$ reaction. This lithium could affect the tensile properties, however no useful evidence has been obtained yet. The effect of aging accelerated by irradiation overshadowed the helium effect

of $\mathrm{nB}$. ${ }^{10} \mathrm{~B} \mathrm{~F}-82 \mathrm{H}$ had a peak of irradiation hardening at the dose of $11 \mathrm{dpa}$ at $400{ }^{\circ} \mathrm{C}$. The irradiation temperatures of 400 and $500^{\circ} \mathrm{C}$ are too high to sustain the irradiation -induced dislocation loop structure. Helium cavities produced in boron-doped F-82H and the irradiation-accelerated aging effect could cause a transient hardening peak at $11 \mathrm{dpa}$.

\section{SUMMARY}

The tensile properties of $8 \mathrm{Cr}-1 \mathrm{~W}-\mathrm{V}-\mathrm{Ta}$ ferritic / martensitic steel (F-82H) irradiated in the HFIR up to $34 \mathrm{dpa}$ at irradiation and test temperatures of 400 and $500^{\circ} \mathrm{C}$ were studied. Some of the steels investigated had ${ }^{10} \mathrm{~B}$ or natural $\mathrm{B}$ added to the material to investigate the helium effect on the tensile properties. The following summarize the observations: 
1. High irradiation hardening occurred at a dose of $11 \mathrm{dpa}$ at $400^{\circ} \mathrm{C}$, but the irradiation hardening observed at higher fluence was not as large.

2. Any helium effects due to ${ }^{10} \mathrm{~B}$ or natural $\mathrm{B}$ were small ${ }^{10} \mathrm{~B}$ F-82H, which had the most helium, had slightly higher strength than STD, but the differences between $\mathrm{nB}$ and STD were not consistent with helium content.

\section{ACKNOWLEDGMENTS}

Research sponsored by the Japan Atomic Energy Research Institute and the Office of Fusion Energy, U.S. Department of Energy; under contract DE-AC05-84OR21400 with Martin Marietta Energy Systems, Inc. The authors are grateful to L.T. Gibson, W.S. Eatherly, and R.L. Martin for tensile testing.

\section{REFERENCES}

[1] M. Tamura, H. Hayakawa, M. Tanimura, A. Hishinuma and T. Kondo, J. Nucl. Mater. 141-143 (1986) 1067-1073.

[2] M. Tamura, H. Hayakawa, A. Yoshitake, A, Hishinuma and T. Kondo, J. Nucl. Mater .155-157 (1988) 620-625.

[3] H. Hayakawa, A. Yoshitake, M. Tamura, S. Natsume, A. Gotoh and A. Hishinuma, J. Nucl. Mater. 189-181 (1991) 693-696.

[4] N. Yamanouchi, M. Tamura, H. Hayakawa, A. Hishinuma and T. Kondo, J. Nucl. Mater. 191-194 (1992) 822-826.

[5] K. Kohno, D.S. Gelles, A. Kohyama, M. Tamura and A. Hishinuma, J. Nucl. Mater. 191-194 (1992) 868-873.

[6] R.L. Klueh and P.J. Maziasz, J. Nucl. Mater. 187 (1992) 43-54.

[7] R.L. Klueh and D.J. Alexander, J. Nucl. Mater. 187 (1992) 60-69.

[8] L.K. Mansur and K. Farrell, J. Nucl. Mater. 170 (1990) 236-245.

[9] J.E. Pawel and R.L. Senn, Fusion Reactor Material Semiannual Progress Report, DOE/ER-0313/12, Office of Fusion Energy (1992) 15-23.

[10] R.L. Klueh and J.M. Vitek, J. Nucl. Mater. 132 (1985) 27-31.

[11] R.L. Klueh and J.M. Vitek, J. Nucl. Mater. 150 (1987) 272-280. 
[12] H. Kurishita, H. Kayano, M. Narui, A. Kimura, M.L. Hamilton and D.S. Gelles, J. Nucl. Mater. 212-215 (1994) 730-735.

[13] D.J. Alexander, et al., " Effects of Radiation on Materials: 17th Volume, ASTM STP 1270, David S. Gelles, Randy K. Nanstad, Arvind S. Kumar and Edward A. Little, Editors, American Society For Testing and Materials, Philadelphia, 1995.

[14] A. Kimura, M. Narui and H. Kayano, J. Nucl. Mater. 191-194 (1992) 879-884. 
(a) $0.2 \%$ offset yield stress

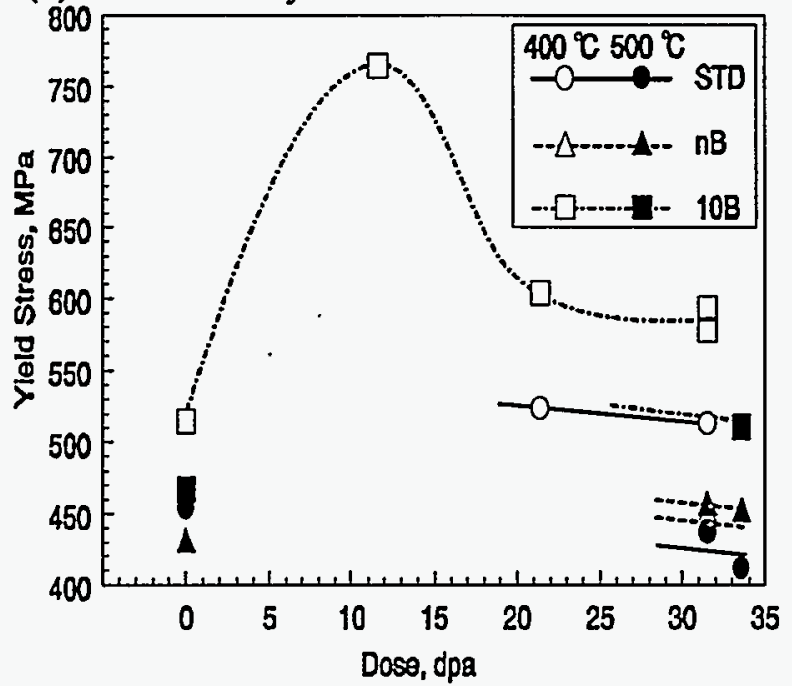

(b) Total elongation

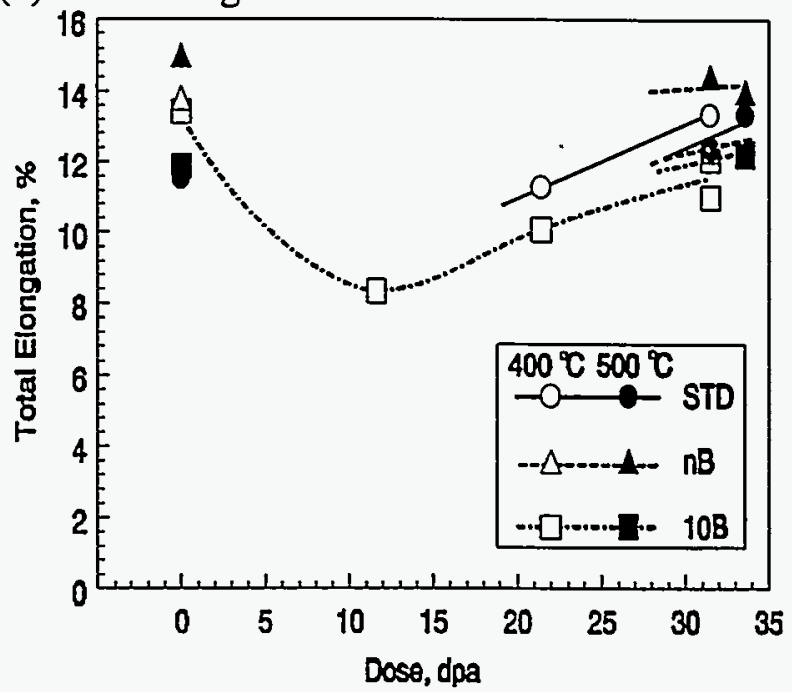

FIG. 1-- $0.2 \%$ offset yield stress (a) and total elongation (b) of F82H (STD, natural B doped and ${ }^{10} \mathrm{~B}$ doped) irradiated in HFIR target position at 400 and $500{ }^{\circ} \mathrm{C}$.

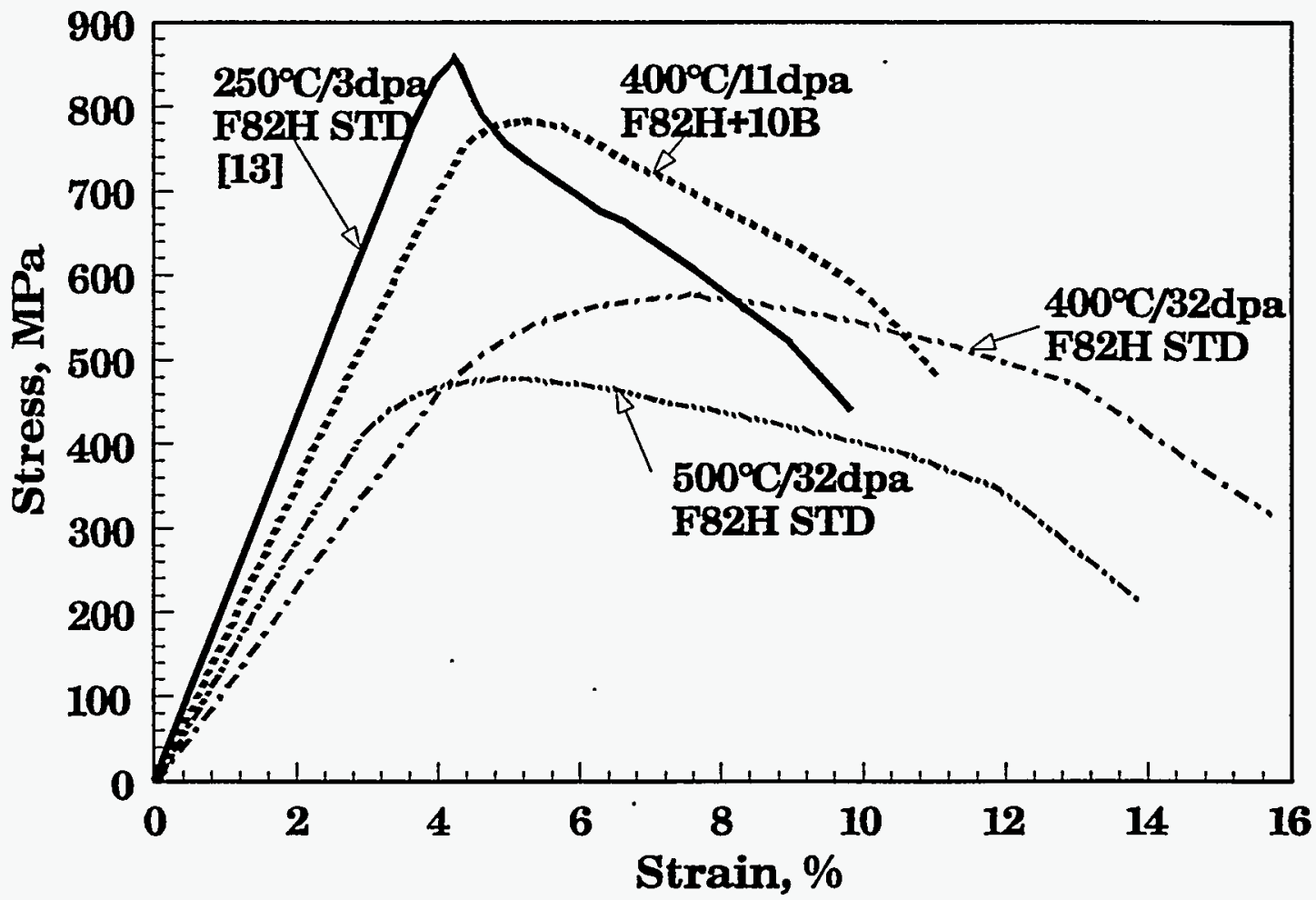

FIG. 2--Stress - strain diagram of F-82H irradiated in HFIR target position.[13] 

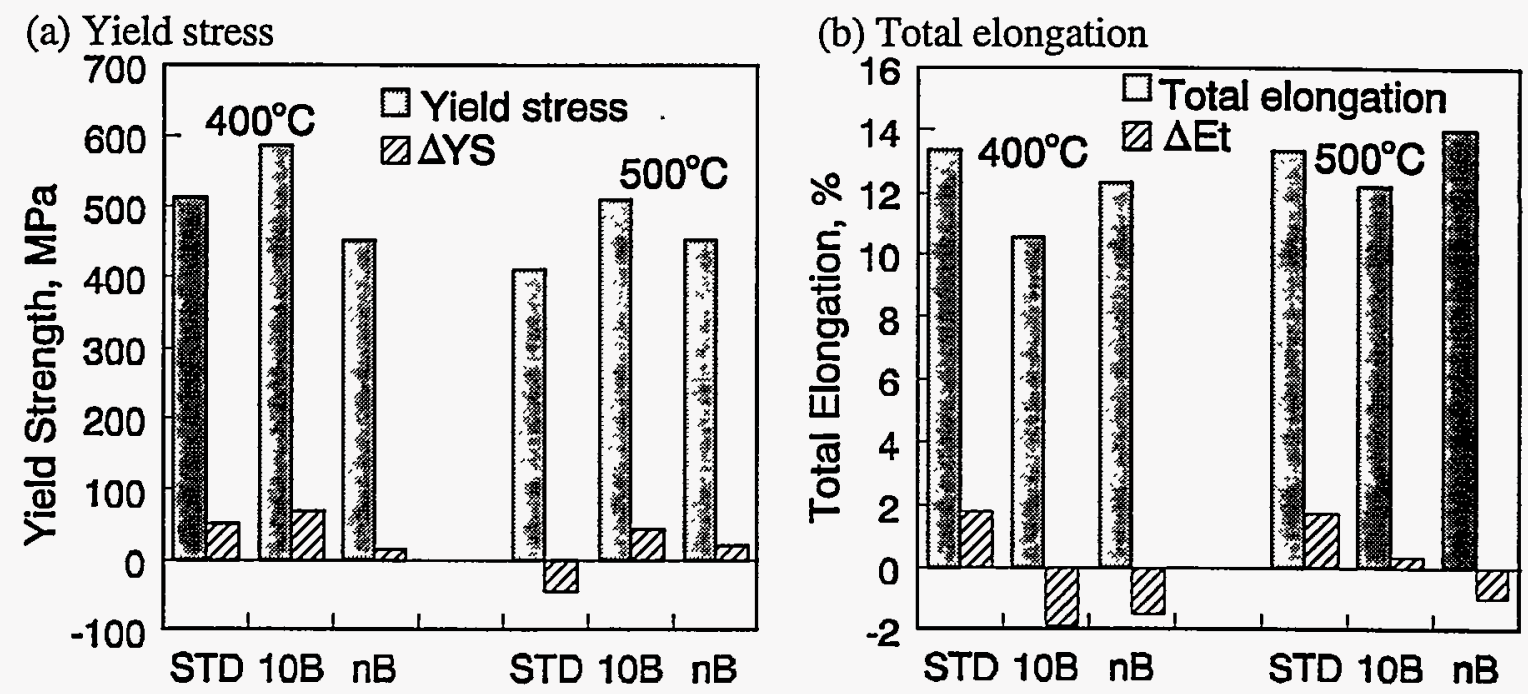

FIG. 3-- Comparison of tensile properties between STD F-82H and boron doped specimens irradiated in HFIR target position. (a) yield stress and (b) total elongation. The changes of yield stress and total elongation due to irradiation are also displayed. 
TABLE 2--The tensile test results of F-82H irradiated in HFIR target position

\begin{tabular}{|c|c|c|c|c|c|c|c|c|c|c|c|c|}
\hline \multirow{3}{*}{ Alloy } & \multicolumn{3}{|c|}{ Irradiation } & \multirow{3}{*}{$\begin{array}{c}\text { Test } \\
\text { Temp. } \\
{ }^{\circ} \mathrm{C}\end{array}$} & \multicolumn{2}{|c|}{ Strength } & \multicolumn{2}{|c|}{$\frac{\text { Elongation }}{}$} & \multicolumn{4}{|c|}{ Increase } \\
\hline & \multirow{2}{*}{$\underset{{ }^{\circ} \mathrm{C}}{\text { Temp. }}$} & \multicolumn{2}{|c|}{ Damage Helium } & & \multirow{2}{*}{$\begin{array}{c}\mathrm{YS} \\
\mathrm{MPa}\end{array}$} & \multirow{2}{*}{$\begin{array}{l}\text { UTS } \\
\mathrm{MPa}\end{array}$} & \multicolumn{2}{|c|}{$\overline{\text { Uniform Total }}$} & \multirow{2}{*}{$\begin{array}{c}\mathrm{YS} \\
\mathrm{MPa}\end{array}$} & \multicolumn{3}{|c|}{ UTS Uniform Total } \\
\hline & & d pa & $\begin{array}{c}\text { a p p m } \\
\mathrm{He}\end{array}$ & & & & $\%$ & $\%$ & & $\mathrm{MPa}$ & $\%$ & $\%$ \\
\hline \multirow[t]{8}{*}{ STD F-82H } & $\ldots$ & 0 & 0 & 250 & 507 & 578 & 3.2 & 13.3 & $\ldots$ & $\ldots$ & $\ldots$ & \\
\hline & 250 & 3 & 1 & 250 & 853 & 856 & 0.3 & 7.8 & 346 & 278 & -2.9 & -5.5 \\
\hline & $\ldots$ & 0 & 0 & 400 & 460 & 534 & 2.5 & 11.5 & $\ldots$ & $\ldots$ & $\ldots$ & $\ldots$ \\
\hline & 400 & 21 & 6 & 400 & 524 & 570 & 2.1 & 11.3 & 64 & 36 & -0.4 & -0.2 \\
\hline & 400 & 32 & 9 & 400 & 513 & 580 & 3.0 & 13.3 & 53 & 46 & 0.5 & 1.8 \\
\hline & $\ldots$ & 0 & 0 & 500 & 455 & 503 & 2.0 & 11.6 & $\ldots$ & $\ldots$ & $\ldots$ & $\cdots$ \\
\hline & 500 & 32 & 9 & 500 & 437 & 478 & 1.8 & 12.4 & -18 & -25 & -0.2 & 0.8 \\
\hline & 500 & 34 & 9 & 500 & 411 & 494 & 2.6 & 13.3 & -44 & -9 & 0.6 & 1.7 \\
\hline \multirow[t]{8}{*}{$F-82 H+10 B$} & $\ldots$ & 0 & 0 & 400 & 515 & 600 & 3.3 & 13.4 & ... & $\ldots$ & $\ldots$ & $\ldots$ \\
\hline & 400 & 12 & 303 & 400 & 764 & 783 & 1.0 & 8.3 & 249 & 183 & -2.3 & -5.1 \\
\hline & 400 & 21 & 306 & 400 & 604 & 642 & 2.0 & 10.1 & 89 & 42 & -1.3 & -3.3 \\
\hline & 400 & 32 & 309 & 400 & 593 & 655 & 3.3 & 12.1 & 78 & 55 & 0 & -1.3 \\
\hline & 400 & 32 & 309 & 400 & 578 & 636 & 3.3 & 11.0 & 63 & 36 & 0 & -2.4 \\
\hline & $\ldots$ & 0 & 0 & 500 & 467 & 514 & 1.9 & 11.9 &. & $\ldots$ & $\ldots$ & $\ldots$ \\
\hline & 500 & 34 & 309 & 500 & 510 & 543 & 2.3 & 12.2 & 43 & 29 & 0.4 & 0.3 \\
\hline & 500 & 34 & 309 & 500 & 512 & 557 & 2.8 & 12.3 & 45 & 43 & 0.9 & 0.4 \\
\hline \multirow[t]{5}{*}{$\mathrm{F}-82 \mathrm{H}+\mathrm{nB}$} & $\ldots$ & 0 & 0 & 400 & 467 & 539 & 3.5 & 13.8 & & $\ldots$ & $\ldots$ & \\
\hline & 400 & 32 & 69 & 400 & 451 & 555 & 2.7 & 12.3 & -16 & 16 & -0.8 & -1.5 \\
\hline & $\ldots$ & 0 & 0 & 500 & 432 & 509 & 3.7 & 15.0 & $\ldots$ & $\cdots$ & $\ldots$ & $\ldots$ \\
\hline & 500 & 32 & 69 & 500 & 457 & 520 & 2.9 & 14.4 & 25 & 11 & -0.8 & -0.6 \\
\hline & 500 & 34 & 69 & 500 & 453 & 504 & 2.7 & 14.0 & 21 & -5 & -1.0 & -1.0 \\
\hline
\end{tabular}

